Article

\title{
A Framework for Multifunctional Green Infrastructure Investment in Camden, NJ
}

\author{
Kate Zidar ${ }^{1}$, Maryse Belliveau-Nance ${ }^{2}$, Anthony Cucchi ${ }^{2}$, Danielle Denk ${ }^{2}$, Andrew Kricun ${ }^{3}$, Shaun O'Rourke ${ }^{2}$, \\ Shudipto Rahman ${ }^{4}$, Sri Rangarajan ${ }^{4}$, Eric Rothstein ${ }^{5}$, Justin Shih ${ }^{5}$ and Franco Montalto ${ }^{1,5} *$ \\ ${ }^{1}$ Department of Civil, Architectural and Environmental Engineering, Drexel University, Philadelphia, PA 19104, USA; \\ E-Mails: katezidar@gmail.com (K.Z.), fam26@drexel.edu (F.M.) \\ 2 The Trust for Public Land, Morristown, NJ 07960, USA; E-Mails: Maryse.Beliveau-Nance@tpl.org (M.B-N.), \\ Anthony.Cucchi@tpl.org (A.C.), danielle.denk@tpl.org (D.D.), sorourke@riib.org (S.O’R.) \\ ${ }^{3}$ Camden County Municipal Utilities Authority, Camden, NJ 08104, USA; E-Mail: andy@ccmua.org \\ ${ }^{4}$ Boomi Environmental LLC, Hillsborough, NJ 08844, USA; E-Mails: shudipto.rahman@gmail.com (S.Rahman), \\ sri@boomi-environmental.com (S.Rangarajan) \\ 5 eDesign Dynamics LLC, New York, NY 10018, USA; E-Mails: justinnnshih@gmail.com (J.S.), \\ erothstein@edesigndynamics.com (E.R.),fmontalto@edesigndynamics.com (F.M.)
}

* Corresponding author

Submitted: 13 May 2017 | Accepted: 28 September 2017 | Published: 30 September 2017

\begin{abstract}
This study demonstrates a decision-support framework for planning Green Infrastructure (GI) systems that maximize urban ecosystem services in Camden, NJ. Seven key ecosystem services are evaluated (urban agriculture expansion, combined sewer overflow reduction, heat island reduction, flooding reduction, capacity building/green jobs expansion, fitness expansion, and stress reduction), to produce a normalized value for each service for each drainage sub-basin within the city. Gaps in ecosystem services are then mapped and utilized to geographically prioritize different kinds of multifunctional GI. Conceptual designs are developed for four site typologies: parks, schools, vacant lots, and brownfield sites. For one demonstration site, additional analysis is presented on urban engagement, life cycle cost reduction, and new sources of funding. What results is an integrated, long-term vision where multifunctional GI systems can be readily customized to meet multiple needs within urban communities. This study provides a portable and replicable framework for leveraging the regulatory requirement to manage stormwater to meet broader urban revitalization goals, all through a decentralized network of green infrastructure assets.
\end{abstract}

\section{Keywords}

ecosystem services; green infrastructure; stormwater management; urban redevelopment

Issue

This article is part of the issue "Smart Solutions for Sustainable Cities", edited by Tom Sanchez (Virginia Tech, USA), Ralph Hall (Virginia Tech, USA) and Nader Afzalan (University of Redlands, USA).

(C) 2017 by the authors; licensee Cogitatio (Lisbon, Portugal). This article is licensed under a Creative Commons Attribution 4.0 International License (CC BY).

\section{Introduction}

Twenty-first century cities face a wide range of challenges, from climate change and reduced federal infrastructure financing to compliance with environmental regulations. While these issues challenge planners ev- erywhere, they are especially difficult in post-industrial cities already struggling to meet the diverse needs of vulnerable populations while handicapped by eroded tax and infrastructure user bases. In this context, there is a need to maximize the possible community benefits associated with any major infrastructure investment. 
Of key interest are multifunctional infrastructure strategies that contribute to economic, environmental, and social bottom lines (Ahern, 2011; Montalto et al., 2012; United States Environmental Protection Agency [US EPA], 2016). This study focuses on the specific opportunity presented by federally mandated stormwater management requirements.

\subsection{Regulatory Context}

The Federal Water Pollution Control Act of 1972, known as the Clean Water Act, requires communities equipped with combined sewers to develop a Long-Term Control Plan (LTCP) to reduce the frequency and volume of combined sewer overflow (CSO). CSOs occur when urban stormwater entering combined sewers exceeds the system capacity, triggering discharge of untreated combined wastewater and stormwater into local water bodies. There are roughly 750 municipalities nationwide (US EPA, 2004) with combined sewers, including some of the largest cities in the Mid-Atlantic, Midwest, and Northeast regions of the United States. In response to federal policy, urban stormwater managers have, over the past two decades, been investigating a wide range of strategies for controlling CSOs, including the use of in-line or end-ofpipe control strategies such as tanks and tunnels. Such centralized grey infrastructure strategies may be effective at reducing CSO frequencies and volumes but can also be both expensive and difficult to site in urban areas where space is limited and land acquisition costs can be relatively high (Montalto et al., 2007).

Many large cities like Philadelphia and New York are instead increasingly opting to comply with federal CSO control policy using a hybrid, decentralized approach (Mittman \& Kloss, 2014). Known generally as Green Infrastructure (GI), this approach seeks to retain, detain, or reuse stormwater at its source. The US EPA (2016) defines GI as "a cost-effective, resilient approach to managing wet weather impacts that provides many community benefits." GI systems may include green roofs, permeable pavements, right-of-way bioswales, constructed wetlands, rain gardens, and a suite of other approaches integrated into the design of streets and parcels.

\subsection{Green Infrastructure and Ecosystem Services}

To significantly reduce CSOs, GI needs to be applied widely within urban watersheds. Municipal GI programs routinely exceed one billion dollars and involve implementation periods spanning multiple decades. While centralized grey infrastructure solutions take many years to design and construct prior to any realized benefit, the decentralized nature of $\mathrm{Gl}$ allows it to be implemented at a flexible pace according to municipal capacity, and start producing immediate tangible benefits. The distributed and phased nature of the GI programs creates new opportunities for adaptively re-imagining the design of streets, parks, buildings, and other urban land uses to address multiple sets of goals. In this way, the need to capture stormwater becomes an opportunity for also replenishing water tables, restoring habitats, beautifying streetscapes, creating opportunities for employment and recreation, raising property values, reducing urban temperature, cleaning the air, sequestering greenhouse gases, and enhancing biodiversity (Dunn, 2010; Grant \& Gallet, 2010; Schilling \& Logan, 2008; US EPA, 2013).

One way of considering these varied benefits is as "ecosystems services," the direct and indirect benefits that humans derive from ecosystems. This term gained widespread use after publication of the Millennium Ecosystem Assessment (MEA, 2005), but only recently has been applied in urban contexts (Miller, 2017). Ecosystem services can be grouped into four general categories: provisioning services (such as food, water, and timber), regulating services (such as regulation of climate, floods, disease), cultural services (such as recreation, aesthetic enjoyment, spiritual fulfillment), and supporting services (such as soil formation, pollination, nutrient cycling). Strategically planned, sited, operated, and maintained, GI systems can provide many different services in each of these categories. By identifying regions within a city in need of certain services, GI planners can infuse local needs and opportunities into decisions regarding what kind of $\mathrm{Gl}$ to introduce into a community, where specifically to build it, and how it might be designed, operated, and maintained.

\subsection{Camden Context}

The city of Camden faces many urban redevelopment challenges such as: high rates of poverty, high unemployment, significant recent population loss, and large numbers of abandoned properties and brownfields. At the time of this study, the Camden County Municipal Utilities Authority (CCMUA) was in the process of developing an LTCP for the City of Camden, and was considering incorporation of GI into this plan. Through the collaborative efforts of the Camden SMART (Stormwater Management and Resource Training) Initiative, some conventional Gl pilot projects had already been implemented throughout the city, though the approach taken to customize these projects to local community needs had not utilized ecosystem services as a driving principle.

This paper first introduces the GI decision-support tool and how it is used to identify ecosystem service opportunities that can be addressed with multifunctional GI systems. Next, the tool is applied to Camden, yielding maps that identify unique sets of ecosystem service opportunities for each drainage area within the city. Finally, a representative group of sites are identified via the framework, and conceptual designs presented, providing an opportunity to visualize multifunctional $\mathrm{Gl}$ as well as dive deeper into associated maintenance, programming, and funding issues.

The goal of this paper is to present a decision-support tool that water utilities can use to customize GI siting, de- 
sign, operation, and maintenance decisions so as to maximize the potential for the resultant GI systems to provide locally valued ecosystem services, while also managing stormwater. Demonstration of the tool in Camden was appropriate because of the many ecosystem service needs of the city, the opportunity it afforded to provide timely input into CCMUA's ongoing LTCP process, and because of the high level of engagement of local stakeholders in stormwater-related issues.

\section{Methodology}

The GI decision-support tool is implemented in four phases. During the first phase, a shortlist of ecosystem services is generated, based on literature review and stakeholder consultation. The second phase uses available data to generate "gap scores" for each ecosystem service within each of the city's drainage sub-basins, specifically identifying priority areas associated with each ecosystem service. In the third phase, individual sites are ranked based on stormwater management potential and observed site characteristics. Finally, a small group of demonstration sites are selected for additional conceptual design development as part of phase four. Each of these phases is discussed in more detail below.

\subsection{Identification and Prioritization of Ecosystem Services}

A literature review was conducted to identify the full range of ecosystem services that could be provided by known GI techniques. Simultaneously, meetings with a diverse set of local stakeholders (government, non-profit, and private stakeholders at the local, state, and federal levels) were held to identify the specific datasets needed to quantify and spatially rank urban ecosystem services needs across the city. The literature review, stakeholder engagement, and subsequent database development culminated in a shortlist of urban ecosystem services deemed appropriate for consideration in the study. These included: urban agriculture expansion, CSO reduction, heat island reduction, flooding reduction, capacity building/green jobs expansion, fitness expansion, and stress reduction.

The ecosystem services that emerged from this process fall into three of the four categories identified by the MEA: provisioning, regulating, and cultural services. Urban agriculture expansion through community gardens is an example of a provisioning service, since these systems can produce food while increasing permeable surface area and reducing runoff. Flooding, CSO, and heat island reduction are examples of regulating services that can be provided by GI, specifically through the ability of vegetated permeable landscapes to provide shade and latent heat transfer, while also collecting and infiltrating stormwater, preventing both surcharges and overflows of the sewer system. Cultural services were more subjectively defined since cultural norms and values are site specific. For the Camden study, three factors that are both linked to human well-being and also related to GI implementation were considered: the availability of outdoor fitness opportunities that could improve physical and mental health, increased access to features that reduce physical stress on individuals, for example tree canopies that produce shading, and access to educational or professional development opportunities.

Note that the selection of ecosystem services that were included in the Camden analysis is not necessarily the same list that would be used in other places, since decisions regarding whether a specific ecosystem function actually constitutes a service are subject to local values (Bolund \& Hunhammar, 1999; Gómez-Baggethun \& Barton, 2013). It is conceivable, and indeed probable, that stakeholders in other locales would identify other combinations of ecosystem services to carry forward in the analysis. The unique incorporation of local values and circumstances into the analysis also explains why no supporting services made it into this particular analysis, though supporting services could certainly become important in studies conducted in other places. The key role that local values play in establishing which ecosystem services are utilized in the analysis also underscores the importance of engaging a representative cohort of local stakeholders in the process.

Once the final list of services was developed to guide the overall analysis, a scoring scheme involving factors and weights was developed to compare the ability of each of the city's drainage sub-basins to provide the service. Factors included in the computation of each service score were selected based on the availability of local information in Camden and weighted based on an evaluation of local risk and exposure pathways. Factors that increased either risk or exposure were included and ranked based on best professional judgment. A summary of this evaluation is presented in Table 1.

\subsection{Area Level Ecosystem Service Gap Score Algorithms}

Algorithms were developed to quantify ecosystem service levels at a neighborhood or "area" scale for drainage sub-basins within the city. Sub-basins are geographic areas that drain to specific CSO outfall locations, and are a common planning unit for stormwater capture. As part of its LTCP planning process, CCMUA must quantify stormwater volumes and water quality impacts (i.e., CSO volume and/or frequency reductions), and modeling activities are typically implemented at the sub-basin level. The median sub-basin size in Camden, approximately $.2 \mathrm{~km}^{2}$, is an ideal area for GI planning, because it is large enough to scale up from individual site-specific GI and monitor cumulative performance, but small enough that measurable outcomes can be observed within a reasonable design and implementation timeline. For planners, this is an important iterative step between demonstration at the site scale and more widespread implementation of a GI program. 
Table 1. Phase one evaluation of ecosystem services.

\begin{tabular}{|c|c|c|c|c|c|}
\hline Category & $\begin{array}{l}\text { Ecosystem } \\
\text { Service } \\
\text { (Description) }\end{array}$ & $\begin{array}{l}\text { Ecosystem } \\
\text { Service } \\
\text { Factor }\end{array}$ & $\begin{array}{l}\text { Factor } \\
\text { Weight }\end{array}$ & Key Data Sets & Notes \\
\hline \multirow[t]{3}{*}{$\begin{array}{l}\text { Provision- } \\
\text { ing }\end{array}$} & \multirow{3}{*}{$\begin{array}{l}\text { Urban } \\
\text { Agriculture } \\
\text { Expansion } \\
\text { (Expansion of } \\
\text { gardening } \\
\text { and farming } \\
\text { opportunities } \\
\text { for food } \\
\text { production) }\end{array}$} & \multirow[b]{2}{*}{ Food Desert } & \multirow[b]{2}{*}{0.500} & $\begin{array}{l}\text { Grocery Store } \\
\text { Locations }\end{array}$ & \multirow{3}{*}{$\begin{array}{l}\text { The } 2008 \text { U.S. Farm Bill (Food, Conservation, } \\
\text { and Energy Act, 2008) describes a food desert } \\
\text { as an area with limited access to affordable } \\
\text { and nutritious food, particularly in lower } \\
\text { income neighborhoods and communities. In } \\
\text { some cases, food production from urban } \\
\text { agriculture can play an important role in food } \\
\text { security, especially during economic and } \\
\text { political crises (Barthel \& Isendahl, 2013). For } \\
\text { this and other categories, population density } \\
\text { is a measurement of exposure. }\end{array}$} \\
\hline & & & & $\begin{array}{l}\text { Community } \\
\text { Garden } \\
\text { Locations }\end{array}$ & \\
\hline & & $\begin{array}{l}\text { Population } \\
\text { Density }\end{array}$ & 0.500 & $\begin{array}{l}\text { Population } \\
\text { Density }\end{array}$ & \\
\hline \multirow[t]{12}{*}{ Regulating } & \multirow{4}{*}{$\begin{array}{l}\text { CSO } \\
\text { Reduction } \\
\text { (Reduction of } \\
\text { number and } \\
\text { frequency of } \\
\text { CSO) }\end{array}$} & & & Average & \multirow{4}{*}{$\begin{array}{l}\text { CCMUA provided annual modeled CSO } \\
\text { volumes for each drainage sub-basin within } \\
\text { the City. Because CSOs are triggered when } \\
\text { stormwater volumes exceed the conveyance } \\
\text { capacity of the collection system, impervious } \\
\text { area coverage was also evaluated as a } \\
\text { contributing factor to CSO reduction. } \\
\text { Impermeable surfaces such as roads, roofs, } \\
\text { parking lots, and sidewalks that store little } \\
\text { water, reduce infiltration of water into the } \\
\text { ground and accelerate runoff to ditches and } \\
\text { streams (Konrad, 2003). }\end{array}$} \\
\hline & & CSO Density & 0.500 & $\begin{array}{l}\text { Annual CSO } \\
\text { Volume }\end{array}$ & \\
\hline & & $\begin{array}{l}\text { Impervious } \\
\text { Cover } \\
\text { Density }\end{array}$ & 0.250 & $\begin{array}{l}\text { Impervious } \\
\text { Area } \\
\text { Coverage }\end{array}$ & \\
\hline & & $\begin{array}{l}\text { Population } \\
\text { Density }\end{array}$ & 0.250 & $\begin{array}{l}\text { Population } \\
\text { Density }\end{array}$ & \\
\hline & \multirow{4}{*}{$\begin{array}{l}\text { Flooding } \\
\text { Reduction } \\
\text { (Reduction of } \\
\text { localized } \\
\text { flooding due } \\
\text { to improper } \\
\text { surface } \\
\text { drainage) }\end{array}$} & $\begin{array}{l}\text { Flood Location } \\
\text { Density }\end{array}$ & 0.400 & $\begin{array}{l}\text { Flooding } \\
\text { Locations }\end{array}$ & \multirow{4}{*}{$\begin{array}{l}\text { CCMUA also provided data on flooding } \\
\text { locations and associated traffic reports. In } \\
\text { addition to the assessment of impervious } \\
\text { coverage, an analysis of average elevations } \\
\text { across the City's drainage sub- basins was } \\
\text { conducted to approximate flood risk due to } \\
\text { low elevations. Exposure was assumed to be } \\
\text { greater at higher population densities. }\end{array}$} \\
\hline & & $\begin{array}{l}\text { Mean } \\
\text { Elevation }\end{array}$ & 0.200 & $\begin{array}{l}\text { State of New } \\
\text { Jersey Digital } \\
\text { Elevation Model }\end{array}$ & \\
\hline & & $\begin{array}{l}\text { Impervious } \\
\text { Cover Density }\end{array}$ & 0.200 & $\begin{array}{l}\text { Impervious Area } \\
\text { Coverage }\end{array}$ & \\
\hline & & $\begin{array}{l}\text { Population } \\
\text { Density }\end{array}$ & 0.200 & $\begin{array}{l}\text { Population } \\
\text { Density }\end{array}$ & \\
\hline & \multirow{4}{*}{$\begin{array}{l}\text { Heat Island } \\
\text { Reduction } \\
\text { (Reduction of } \\
\text { local ground } \\
\text { surface tem- } \\
\text { peratures) }\end{array}$} & $\begin{array}{l}\text { Tree Cover } \\
\text { Density }\end{array}$ & 0.250 & $\begin{array}{l}\text { Tree Canopy } \\
\text { Cover }\end{array}$ & \multirow{4}{*}{$\begin{array}{l}\text { The urban heat island effect is the } \\
\text { phenomenon whereby urban regions } \\
\text { experience warmer temperatures than their } \\
\text { rural surroundings (US EPA, 2008). Impervious } \\
\text { areas heat up more readily than vegetated } \\
\text { pervious ones and are thus a key factor in } \\
\text { evaluating the extent of the heat island } \\
\text { coverage. Tree canopy coverage obtained } \\
\text { from a } 2011 \text { study by the U.S. Department of } \\
\text { Agriculture was utilized to gain an } \\
\text { understanding of existing tree density in } \\
\text { Camden. Urban forests ameliorate climate } \\
\text { through: shading, evapotranspiration, and } \\
\text { airflow modification, which affects the } \\
\text { transport and diffusion of energy, water } \\
\text { vapor, and pollutants (Nowak \& McPherson, } \\
\text { 1993). Furthermore, the National } \\
\text { Collaborating Centre for Environmental } \\
\text { Health (2010) identifies populations } \\
\text { vulnerable to heat stress (children under the } \\
\text { age of 5, adults over the age of 65) as a focus } \\
\text { for heat island reduction. }\end{array}$} \\
\hline & & $\begin{array}{l}\text { Heat- } \\
\text { Vulnerable } \\
\text { Population } \\
\text { Density }\end{array}$ & 0.250 & $\begin{array}{l}\text { Heat-Vulnerable } \\
\text { Population } \\
\text { Density } \\
(<5,>65)\end{array}$ & \\
\hline & & $\begin{array}{l}\text { Impervious } \\
\text { Cover Density }\end{array}$ & 0.250 & $\begin{array}{l}\text { Impervious } \\
\text { Area Coverage }\end{array}$ & \\
\hline & & $\begin{array}{l}\text { Population } \\
\text { Density }\end{array}$ & 0.250 & $\begin{array}{l}\text { Population } \\
\text { Density }\end{array}$ & \\
\hline
\end{tabular}


Table 1. Phase one evaluation of ecosystem services. (Cont.)

\begin{tabular}{|c|c|c|c|c|c|}
\hline Category & $\begin{array}{l}\text { Ecosystem } \\
\text { Service } \\
\text { (Description) }\end{array}$ & $\begin{array}{l}\text { Ecosystem } \\
\text { Service } \\
\text { Factor }\end{array}$ & $\begin{array}{l}\text { Factor } \\
\text { Weight }\end{array}$ & Key Data Sets & 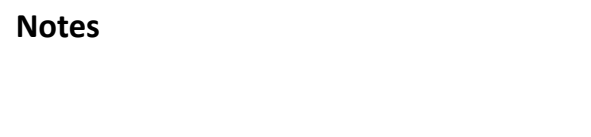 \\
\hline \multirow[t]{13}{*}{ Cultural } & \multirow{3}{*}{$\begin{array}{l}\text { Capacity } \\
\text { Building and } \\
\text { Green Job } \\
\text { Expansion } \\
\text { (Expansion of } \\
\text { education, } \\
\text { professional } \\
\text { development, } \\
\text { and } \\
\text { employment } \\
\text { opportunities) }\end{array}$} & $\begin{array}{l}\text { Capacity } \\
\text { Building } \\
\text { Opportunities }\end{array}$ & 0.500 & $\begin{array}{l}\text { Environmental } \\
\text { Community } \\
\text { Organization } \\
\text { Locations } \\
\text { Public Elementary } \\
\text { and Secondary } \\
\text { School Locations }\end{array}$ & \multirow{3}{*}{$\begin{array}{l}\text { Exposure to nature and green space provides } \\
\text { multiple opportunities for cognitive } \\
\text { development, which increases the potential } \\
\text { for stewardship of the environment and for a } \\
\text { stronger recognition of ecosystem services } \\
\text { (Krasny \& Tidball, 2009; Tidball \& Krasny, } \\
\text { 2010). As an example, urban forests and } \\
\text { allotment gardens are often used for } \\
\text { environmental education purposes (Gröning, } \\
\text { 1995; Tyrväinen, Pauleit, Seeland, \& de Vries, } \\
\text { 2005) and facilitate cognitive coupling to } \\
\text { seasons and ecological dynamics in } \\
\text { technological and urbanized landscapes. This } \\
\text { service addresses the issue of who } \\
\text { participates in urban redevelopment, who } \\
\text { benefits from the work of GI, and how } \\
\text { (Campbell, 2014). }\end{array}$} \\
\hline & & $\begin{array}{l}\text { Median } \\
\text { Household } \\
\text { Income }\end{array}$ & 0.250 & $\begin{array}{l}\text { Median } \\
\text { Household } \\
\text { Income }\end{array}$ & \\
\hline & & $\begin{array}{l}\text { Unemployment } \\
\text { Rate }\end{array}$ & 0.250 & $\begin{array}{l}\text { Unemployment } \\
\text { Rate }\end{array}$ & \\
\hline & \multirow{4}{*}{$\begin{array}{l}\text { Fitness } \\
\text { Opportunity } \\
\text { Expansion } \\
\text { (Expansion of } \\
\text { access to } \\
\text { outdoor } \\
\text { destinations } \\
\text { for fitness) }\end{array}$} & $\begin{array}{l}\text { Outdoor } \\
\text { Destination }\end{array}$ & 0.500 & $\begin{array}{l}\text { Public Park } \\
\text { Locations }\end{array}$ & \multirow{4}{*}{$\begin{array}{l}\text { Individuals below retirement age with greater } \\
\text { exposure to green space reportedly have } \\
\text { lower rates of mortality (Mitchell \& Popham, } \\
\text { 2007). The body mass index of children has } \\
\text { been shown to have an inverse relationship to } \\
\text { exposure to green space (Bell, Wilson, \& } \\
\text { Liu., 2008). }\end{array}$} \\
\hline & & Density & & $\begin{array}{l}\text { Community } \\
\text { Garden Locations }\end{array}$ & \\
\hline & & $\begin{array}{l}\text { Median } \\
\text { Household } \\
\text { Income }\end{array}$ & 0.250 & $\begin{array}{l}\text { Population } \\
\text { Density }\end{array}$ & \\
\hline & & $\begin{array}{l}\text { Population } \\
\text { Density }\end{array}$ & 0.250 & $\begin{array}{l}\text { Median } \\
\text { Household } \\
\text { Income }\end{array}$ & \\
\hline & \multirow{6}{*}{$\begin{array}{l}\text { Stress } \\
\text { Reduction } \\
\text { (Expansion of } \\
\text { access to } \\
\text { stress } \\
\text { reduction } \\
\text { features) }\end{array}$} & Stress & & $\begin{array}{l}\text { Mental Health } \\
\text { Service Centers }\end{array}$ & \multirow{6}{*}{$\begin{array}{l}\text { When exposed to natural environments, } \\
\text { stress levels decrease rapidly, whereas during } \\
\text { exposure to urban environments, stress levels } \\
\text { remain high or even increase (Ulrich et al., } \\
\text { 1991). Another study on recovery of patients } \\
\text { in a hospital showed that patients with rooms } \\
\text { facing a park had } 10 \% \text { faster recovery and } \\
\text { needed } 50 \% \text { less strong pain-relieving } \\
\text { medication compared to patients in rooms } \\
\text { facing a building wall (Ulrich, 1984). }\end{array}$} \\
\hline & & $\begin{array}{l}\text { Reduction } \\
\text { Services } \\
\text { Density }\end{array}$ & 0.500 & $\begin{array}{l}\text { Public Park } \\
\text { Locations }\end{array}$ & \\
\hline & & & & $\begin{array}{l}\text { Community } \\
\text { Garden Locations }\end{array}$ & \\
\hline & & $\begin{array}{l}\text { Median } \\
\text { Household } \\
\text { Income }\end{array}$ & 0.167 & $\begin{array}{l}\text { Median } \\
\text { Household } \\
\text { Income }\end{array}$ & \\
\hline & & $\begin{array}{l}\text { Unemployment } \\
\text { Rate }\end{array}$ & 0.167 & $\begin{array}{l}\text { Unemployment } \\
\text { Rate }\end{array}$ & \\
\hline & & $\begin{array}{l}\text { Population } \\
\text { Density }\end{array}$ & 0.167 & $\begin{array}{l}\text { Population } \\
\text { Density }\end{array}$ & \\
\hline
\end{tabular}

The algorithms mathematically combine different spatially differentiated variables. A value for each of these variables was developed for each sub-basin area as a normalized value between 0 and 1 , where 1 represents the highest priority, and 0 represents the lowest. Informed by the stakeholder engagement process, weights were also assigned based on the anticipated impact of each variable to each service. The summation of the weighted factors equals the service gap score such that:

$$
\begin{gathered}
S G_{i}=\left(W_{1} \times V_{1}\right)+\left(W_{2} \times V_{2}\right)+\ldots+\left(W_{n} \times V_{n}\right) \\
S G N_{i}=\frac{S G_{i}-S G_{\min }}{S G_{\max }-S G_{\min }}
\end{gathered}
$$

with $S G_{i}=$ raw service gap score, $W=$ weight value, $V=$ variable value and $S G N=$ service gap score normalized. 
For example, the service gap score for the ecosystem service of "urban agriculture expansion" considers population density within the sub-basin and its "food desert" density, defined as the relative prevalence of grocery stores and community gardens. Sub-basins with high population density and high food desert density (i.e., fewer grocery stores and community gardens) relative to the city mean were awarded the lowest ecosystem service levels. Areas with the lowest ecosystem service levels had the highest ecosystem service gap score for this service. Gl systems conceived for areas with a high urban agriculture gap score would ideally be designed to include food production capacity such as vegetable gardens or orchards.

With the gap scores for each of the seven target ecosystem services within each sub-basin, a composite score was generated. Although various weighting schemes could be used for combining the individual ecosystem service gap scores, including through a participatory stakeholder program, an arithmetic average was used here for demonstration purposes. The composite gap score was utilized to rank the sub-basins in order of highest composite service gap score to the lowest, allowing different drainage sub-basins to be compared to one another using a common metric, and prioritize specific drainage sub-basins for GI implementation. Sub-basins with the highest composite gap-scores were assigned the highest priority in the next phase of work.

\subsection{Site Selection and Prioritization}

Based on an evaluation of gap scores, land tenure, and field investigation, potential sites for multifunctional GI were identified and prioritized. In terms of tenure, emphasis was placed on public properties (e.g., schools and parks), abandoned sites, and brownfield sites, because of synergies with the interests of CCMUA. A total of 18 schoolyards, parks, vacant lands, and brownfields were identified within the highest priority sub basins. Further refinement of the 18 sites was performed through field investigations conducted by the project team. These field investigations evaluated both the specific ecosystem service opportunities and the "park development impact," a metric used by The Trust for Public Land (TPL, 2004) to assess $\mathrm{GI}$ potential in other jurisdictions (see Table 2).

\subsection{Ecosystem Service Driven Conceptual Design Process}

To visualize potential multifunctional GI, the four topranking sites were utilized for further conceptual design development. First, the volume of stormwater generated on directly connected and adjacent impervious surfaces was estimated. Directly connected surfaces are defined as impervious spaces already graded towards the site. Stormwater from adjacent surfaces, by contrast, could theoretically be conveyed to the site using trench drains, pipes, or other hydraulic appurtenances, even if the surfaces themselves were not graded towards the future $\mathrm{Gl}$ site. Next, the potential site features that could help to address the top three ecosystem service gap scores of the respective sub-basin were identified. Multiple features were incorporated into each site so as to demonstrate the range of options that could be considered in a future participatory process focused on developing final designs.

\section{Results and Discussion}

\subsection{Area Level Ecosystem Service Gap Score Model Results}

The composite service gap scores (with equal weighting of the services) are presented in Figure 1 and can be utilized as a general indicator of the portions of the city that could benefit most from multifunctional GI projects. The individual gap scores are presented (with equal interval categories, $0-0.20,0.21-0.40,0.41-0.60,0.61-0.80$, and 0.81-1.00) in Figure 2 for the seven individual ecosystem services considered for the Camden study. All of the scores can also be accessed in digital form through TPL's GI Opportunity Mapping GIS Viewer (for access information please contact the authors).

Table 2. A description of the qualitative factors assessed and compared during multifunctional Gl site prioritization.

\begin{tabular}{ll}
\hline Factor & Description \\
\hline Potential community impact & $\begin{array}{l}\text { Quantified by determining the number of people who live within a 10-minute walk } \\
\text { of the site, and reviewing patterns of pedestrian and vehicular circulation. }\end{array}$ \\
\hline $\begin{array}{ll}\text { Potential volume of stormwater } \\
\text { managed }\end{array}$ & $\begin{array}{l}\text { Potential volumes of stormwater based on topography, infrastructure, and other } \\
\text { factors. }\end{array}$ \\
\hline Potential for site improvements & $\begin{array}{l}\text { Sites with the greatest need for physical improvement were ranked higher than } \\
\text { those that were already in reasonable physical condition. }\end{array}$ \\
\hline Potential for 'eyes-on-the-site' & $\begin{array}{l}\text { A determination of site visibility, à la urbanist Jane Jacobs, which translates to how } \\
\text { likely it is to be safe and secure or require additional repair and maintenance. }\end{array}$ \\
\hline $\begin{array}{l}\text { Qualitative review of social } \\
\text { conditions on and around the site }\end{array}$ & $\begin{array}{l}\text { Sites that provided greater opportunities for partnership were favored over those } \\
\text { offering fewer partnerships. }\end{array}$ \\
\hline
\end{tabular}




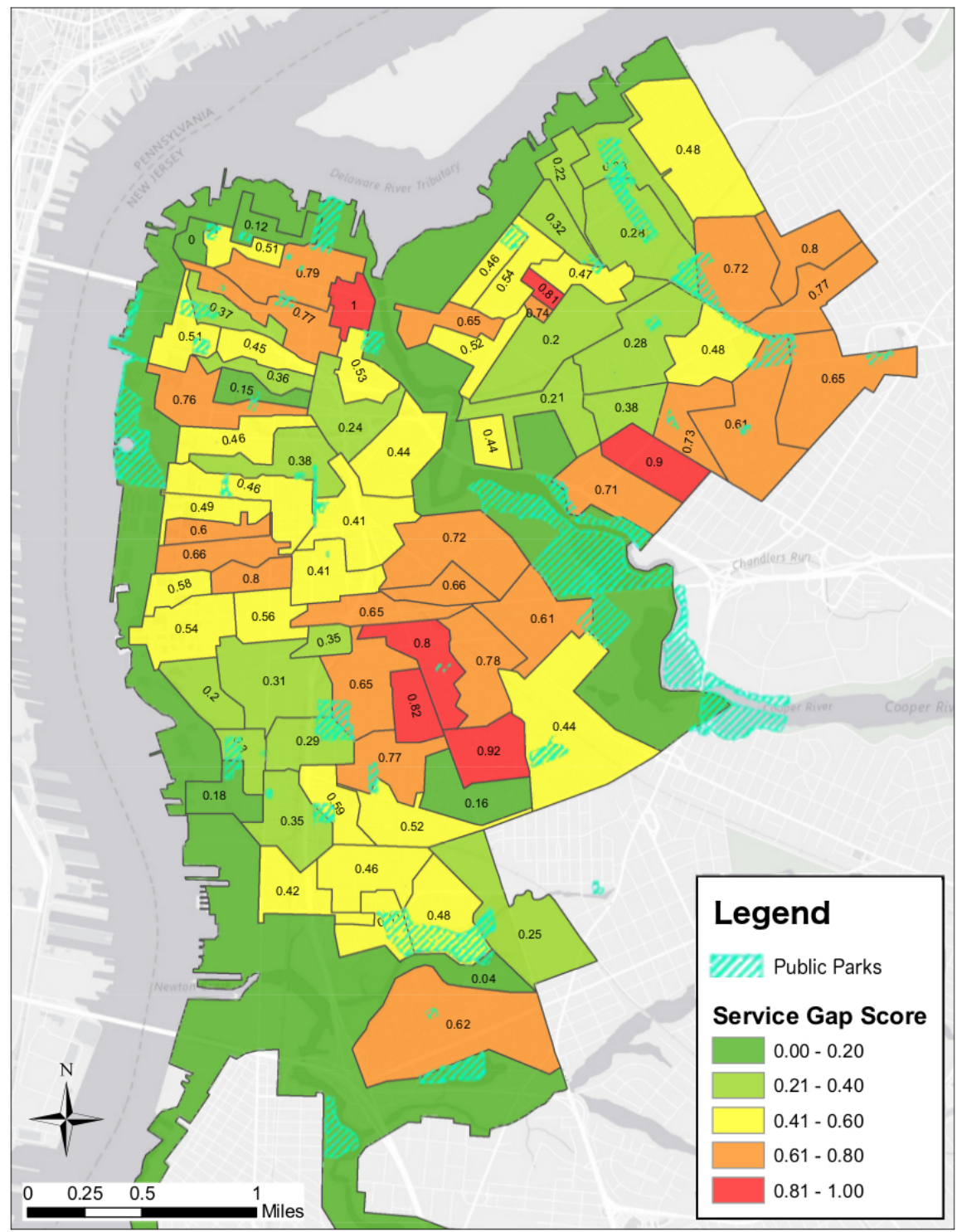

Figure 1. Combined ecosystem service gap score map for the city of Camden, NJ.

Visible differences in individual ecosystem service gap scores across the city's sub-basins suggest that the model algorithms successfully identified gradients in conditions. The ecosystem service gap scores were normalized and thus represent a relative ranking of ecosystem service needs. Lower scoring sub-basins are not necessarily without need, but rather are less in need of a particular service than other portions of the city. By contrast, the highest ranked sub-basins are estimated to benefit most from $\mathrm{Gl}$ designed to maximize specific services.

Table 3 displays the individual service gap scores for the top 16 ranked sub-basins $\left(20^{\text {th }}\right.$ percentile, combined score). The table shows that the highest ranked services vary for each basin, suggesting an opportunity to customize GI selection, siting, and design decisions to neighborhood conditions. In the conceptual design process, the composite scores were utilized in site selection, while the top three individual gap scores were used to guide development of the key site design features.

\subsection{Site Selection and Prioritization Results}

Following our evaluation of gap scores and field investigations, a total of 18 sites were selected and prioritized. The strongest candidates in each land tenure type (schoolyard, park, vacant land, and brownfield) were identified for further analysis, and are described below. (For access to the complete site selection and prioritization matrix, please contact the authors).

The highest ranked park site was Alberta Woods Park. This site emerged as an exemplary candidate site because of its high visibility and potential ability to manage stormwater from the adjacent right-of-way (ROW) within the boundaries of the park. The park is in a densely populated residential area and is adjacent to a well-traveled vehicular route. In addition, local students at the nearby Francis X McGraw Elementary School can easily access and benefit from the site. The conceptual designs developed for Alberta Woods Park would thus provide a posi- 


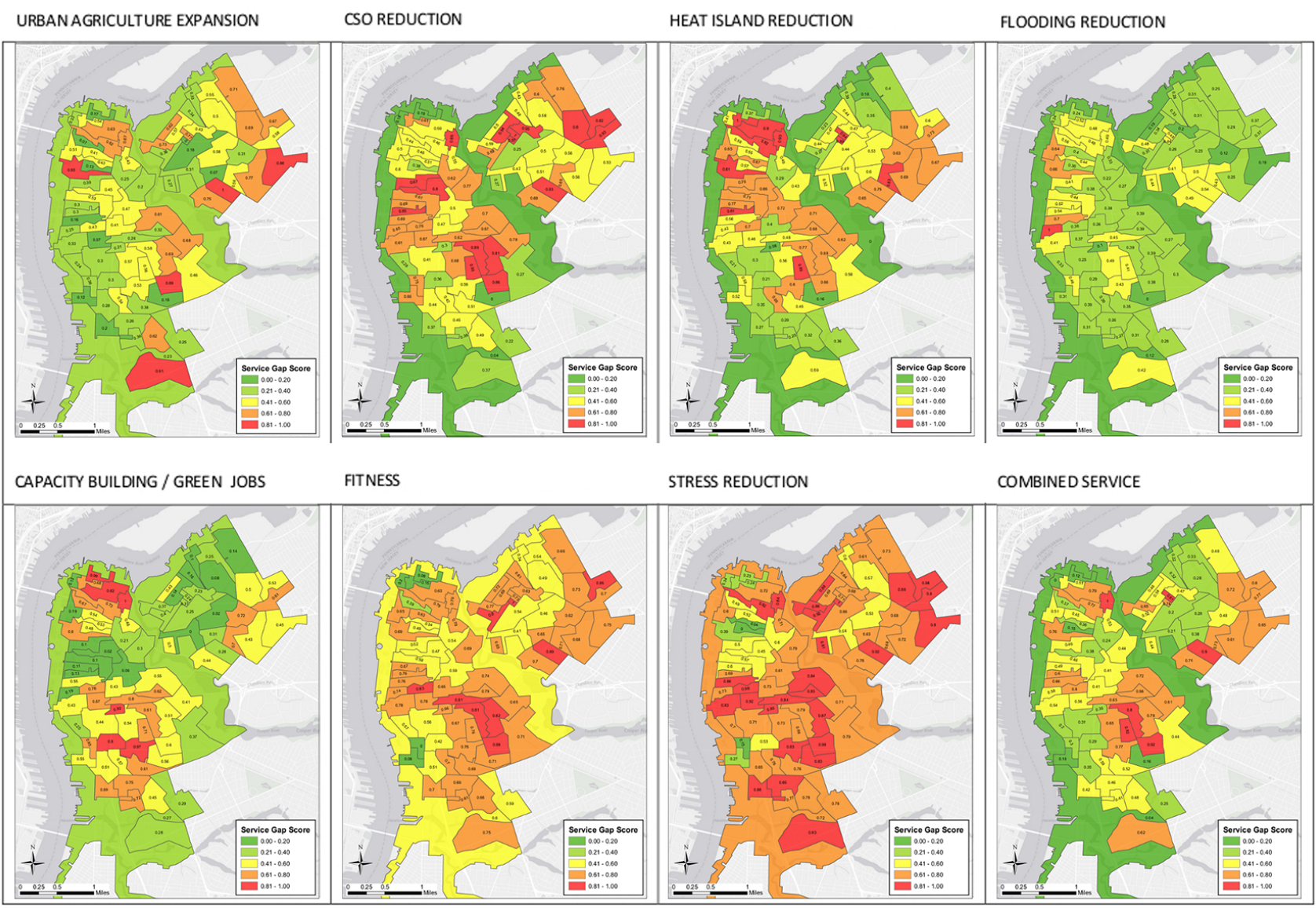

Figure 2. Individual gap score map for each ecosystem service evaluated.

Table 3. Top $20^{\text {th }}$ percentile sub-basins for combined service gap score.

\begin{tabular}{|c|c|c|c|c|c|c|c|c|c|}
\hline \multirow[b]{2}{*}{$\begin{array}{l}\text { Sewer } \\
\text { Sub- } \\
\text { Basin } \\
\text { ID }\end{array}$} & \multirow[b]{2}{*}{$\begin{array}{l}\text { Catchment } \\
\text { Area } \\
\left(\mathrm{km}^{2}\right)\end{array}$} & \multicolumn{8}{|c|}{ Service Gap Score } \\
\hline & & Combined & $\begin{array}{l}\text { Urban } \\
\text { Agriculture }\end{array}$ & $\begin{array}{l}\text { CSO } \\
\text { Reduction }\end{array}$ & $\begin{array}{l}\text { Heat } \\
\text { Island }\end{array}$ & $\begin{array}{l}\text { Flooding } \\
\text { Reduction } \\
\text { Reduction }\end{array}$ & $\begin{array}{l}\text { Capacity } \\
\text { Building / } \\
\text { Green Jobs } \\
\text { Expansion }\end{array}$ & $\begin{array}{l}\text { Fitness } \\
\text { Expansion }\end{array}$ & $\begin{array}{l}\text { Stress } \\
\text { Reduction }\end{array}$ \\
\hline C15 & .10 & 1.00 & 0.67 & 0.85 & 0.93 & 0.49 & 1.00 & 0.79 & 0.84 \\
\hline C3-8 & .21 & 0.92 & 0.89 & 0.86 & 0.66 & 0.38 & 0.60 & 0.88 & 0.99 \\
\hline C27-2 & .20 & 0.90 & 1.00 & 0.83 & 0.75 & 0.54 & 0.28 & 0.89 & 0.92 \\
\hline C3-10 & .14 & 0.82 & 0.56 & 0.93 & 0.85 & 0.41 & 0.71 & 0.76 & 0.69 \\
\hline$C 22 A-3$ & .04 & 0.81 & 0.77 & 1.00 & 0.94 & 0.48 & 0.24 & 0.73 & 0.71 \\
\hline C3-5 & .23 & 0.80 & 0.58 & 0.89 & 0.77 & 0.39 & 0.61 & 0.81 & 0.79 \\
\hline C6-2 & .11 & 0.80 & 0.43 & 0.76 & 0.70 & 0.36 & 0.76 & 0.83 & 0.98 \\
\hline C90-3 & .21 & 0.80 & 0.67 & 0.82 & 0.60 & 0.37 & 0.53 & 0.85 & 0.98 \\
\hline C13-2 & .28 & 0.79 & 0.63 & 0.59 & 0.90 & 0.48 & 0.82 & 0.63 & 0.72 \\
\hline C3-6 & .28 & 0.78 & 0.69 & 0.81 & 0.68 & 0.39 & 0.51 & 0.82 & 0.87 \\
\hline C11-3 & .23 & 0.77 & 0.62 & 0.46 & 0.82 & 0.48 & 0.73 & 0.79 & 0.82 \\
\hline C90-4 & .23 & 0.77 & 0.58 & 0.93 & 0.73 & 0.37 & 0.61 & 0.70 & 0.80 \\
\hline C3-9 & .23 & 0.77 & 0.53 & 0.56 & 0.60 & 0.43 & 0.97 & 0.76 & 0.83 \\
\hline C10-1 & .24 & 0.76 & 0.93 & 0.60 & 0.81 & 0.66 & 0.60 & 0.69 & 0.39 \\
\hline C22A-2 & .02 & 0.74 & 0.00 & 0.97 & 0.89 & 0.44 & 0.31 & 1.00 & 1.00 \\
\hline C22-6 & .19 & 0.73 & 0.56 & 0.65 & 0.83 & 0.43 & 0.70 & 0.71 & 0.68 \\
\hline
\end{tabular}


tive example of stormwater management for direct public benefit within an existing park.

The highest ranked schoolyard site was Sumner Elementary School. The site emerged as an exemplary candidate site principally because of its vast impervious surface area, but also because of its potential for increasing recreational opportunities for local students. This school is located within the Whitman Park Choice Neighborhood boundary, making it also potentially eligible for grant funding. The schoolyard currently includes no physical amenities for the children who attend classes. Sumner Elementary was thus selected as an opportunity to demonstrate how stormwater management could be integrated into schoolyard redevelopment.

The highest ranked vacant site was a series of interconnected lots located at the intersection of Vine and Willard in North Camden. These lots could be combined to create a new park that would manage both on-site and ROW stormwater. In addition, this site is located in a park-poor area of Camden with a high number of residents who live within a 10-minute walk, and is adjacent to religious institutions. There are no known zoning or other regulatory conditions that restrict the type of redevelopment possible at this site. A complete Environmental Assessment would, however, be recommended prior to start of work on any site. This collection of lots was selected to demonstrate how vacant land could be aggregated and transformed into a multifunctional stormwater park with multiple community benefits.
The brownfield site selected for conceptual design development was Camden Labs. While this was not the highest ranked site, the selection and prioritization process revealed this site's great potential to integrate GI systems into an in-process proposal for redevelopment to be undertaken by the Camden Redevelopment Authority and other stakeholders. The site provides a unique opportunity to integrate stormwater management into sustainable housing design, urban homesteading, and a complete sustainable site development.

\subsection{Conceptual Design for Four Demonstration Sites}

The composite gap scores and site selection matrix directly informed the choice of sites in each of four site typologies: parks, schools, vacant lots, and brownfield sites. Basic design parameters, and a conceptual site plan for multifunctional $\mathrm{GI}$ is included for each location in Figures 3-6. The designs present elements that respond to the top ecosystem service gaps identified in this analysis (note inset on each site plan).

\subsection{Interpreting and Using the Results}

The sites selected and the conceptual designs presented are the results of the ecosystem service gap scores as they are valued in the decision-support framework, assuming equal weighting of constituent services. Thus, they represent only one vision of how these sites could

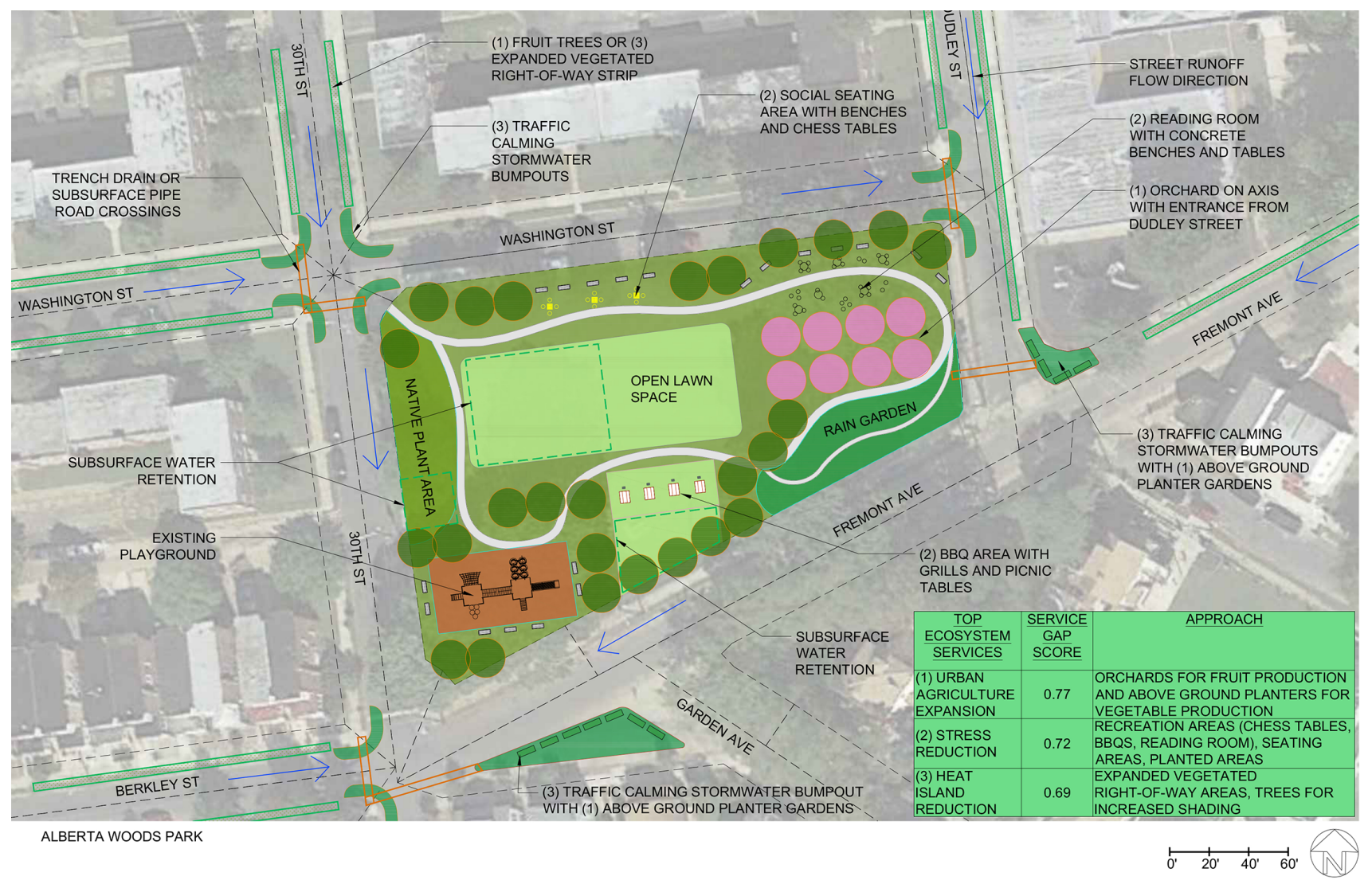

Figure 3. Alberta Woods Park concept plan. 


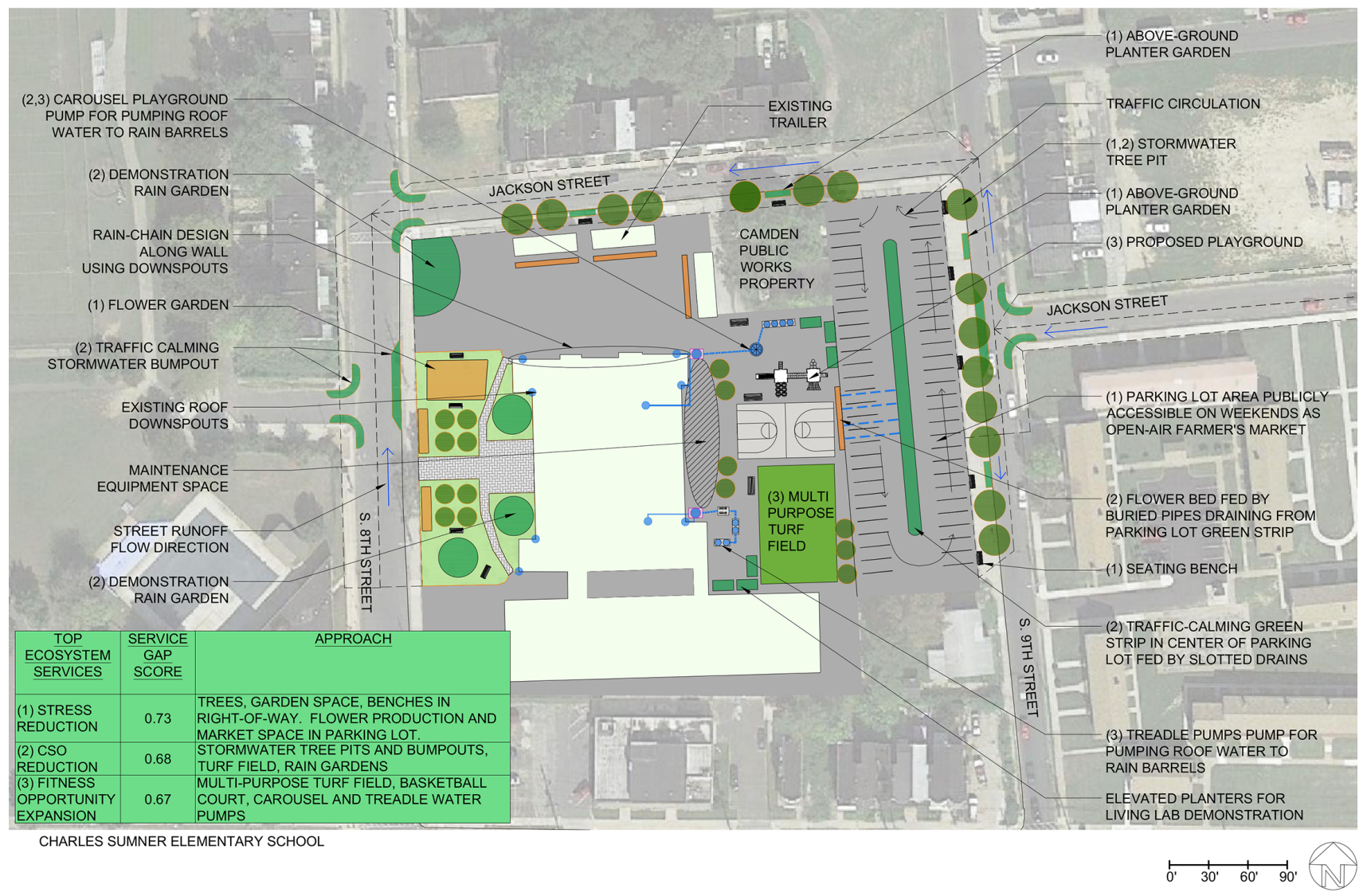

Figure 4. Sumner Elementary School concept plan.

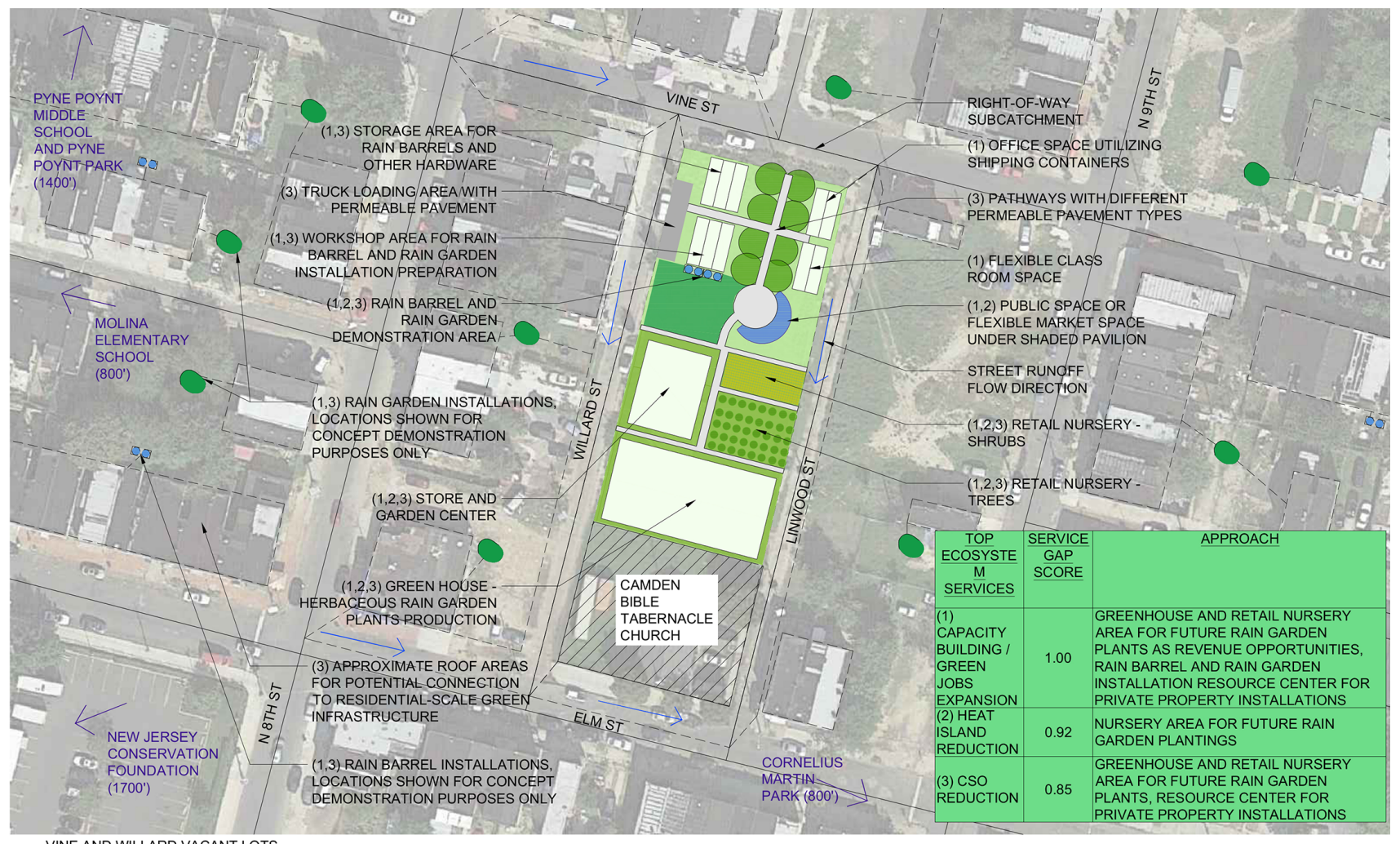

VINE AND WILLARD VACANT LOTS

$$
\begin{array}{llllll}
\hline 0^{\prime} & 25^{\prime} & 50^{\prime} & 75^{\prime} & 100^{\prime} & \\
\hline
\end{array}
$$

Figure 5. Vine and Willard vacant lots concept plan. 


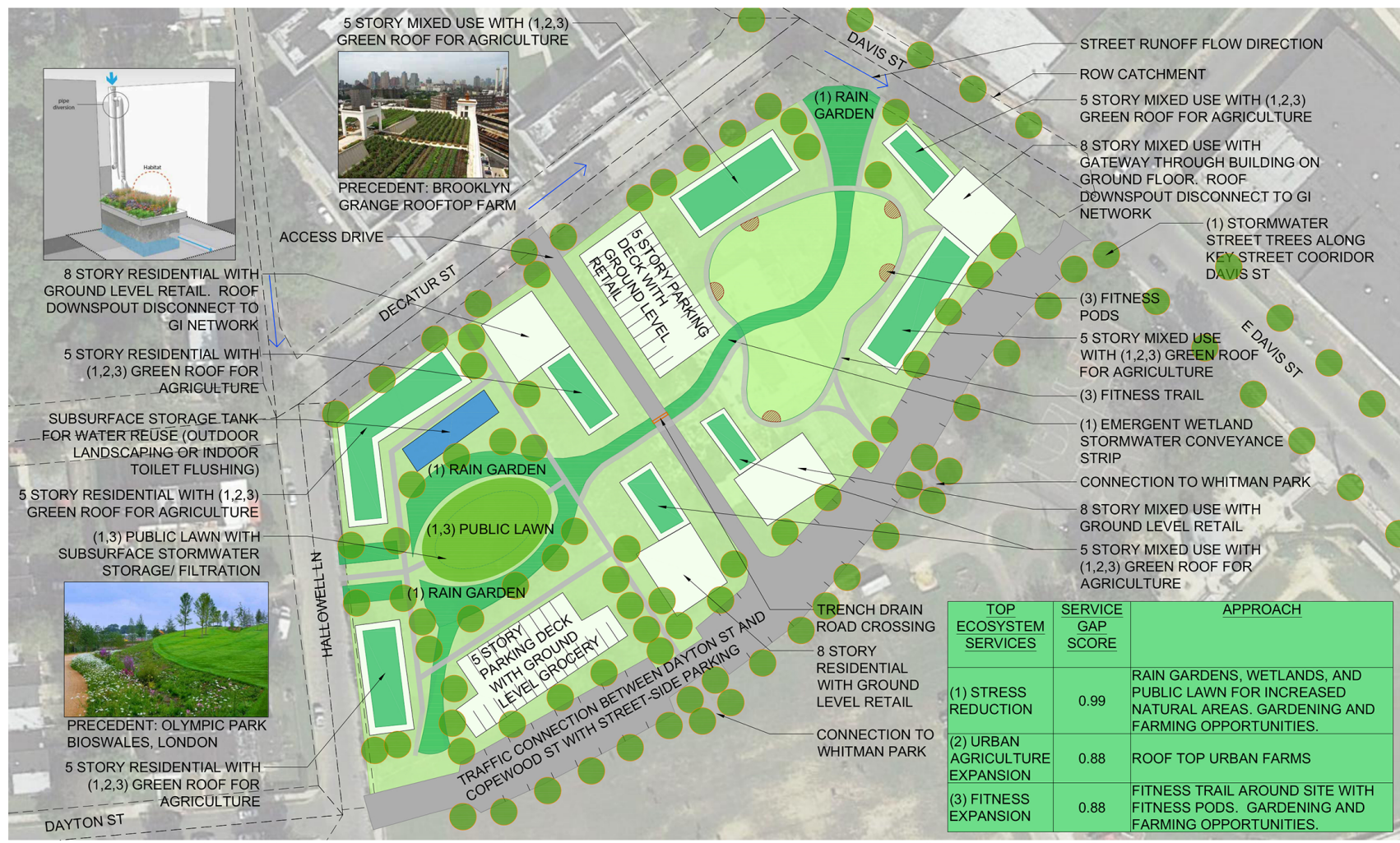

FORMER CAMDEN LABS

Figure 6. Former Camden Labs stormwater assessment.

be redesigned for multifunctionality. In future analyses, the weighting scheme could be locally tailored through stakeholder engagement. Dialogue about the ecosystem services could be used to elucidate where stakeholders already agree and where additional debate and fact gathering is necessary to build consensus about neighborhood needs. Such a process is important for GI priority setting, but is also more generally valuable in community goal setting.

For example, in a particular jurisdiction, the consultants engaged in the LTCP planning process may be principally focused on the regulatory mandates associated with CSO reduction and/or the public nuisance associated with flooding, and be less aware of other community needs that could potentially be addressed by GI. During a meeting with stakeholders, members of a local senior center could, for example, articulate the difficulty that the elderly feel waiting for buses in the hot sun, and an individual representing the local planning board could inform the group of a new permit issued to open a new supermarket. The resulting deliberation might result in an across-the-board increase in the weight assigned to the heat island service provided by GI, and a localized reduction to the weight given to urban agriculture in the region immediately surrounding the new supermarket. These changes would result in different spatial priorities for $\mathrm{Gl}$, and different constituent services guiding their design. In this way, local knowledge and preferences are incorporated directly into the Gl planning process, while the deliberation also promotes education, and creates new partnerships between the community and local governmental decision-makers.

The conceptual designs presented emerge from application of the new decision-support tool to Camden, and present customized strategies for utilizing multifunctional GI investments to manage stormwater, while also addressing other community needs, and potentially attracting new interest and funding in GI as an urban policy initiative. To further explore this potential multifunctional role for $\mathrm{GI}$ in $21^{\text {st }}$ century cities, additional analysis is presented for the Vine and Willard site.

\subsubsection{Vine and Willard Vacant Lots-Urban Engagement Through GI Investment}

The Vine and Willard site is an agglomeration of twelve vacant lots at the core of a residential area. The Camden Bible Tabernacle Church sits on the only actively used lot within the block. The collection of lots comprises $2,428 \mathrm{~m}^{2}$ of pervious grass area, with individual lots owned by the City of Camden as well as some private landlords. While the effort required to synchronize a re-appropriation of these lots for GI may be significant, a concerted effort to do so, for example through the development of a land bank, may be warranted, since similar configurations of vacant or quasi-vacant blocks are common throughout Camden. Analysis of this site is presented as an example of the potential benefits of 
attempting to remedy this challenging urban condition with a Gl strategy.

The overall vision is to leverage $\mathrm{Gl}$ investments on the block to create a "neighborhood green infrastructure hub". While actively managing stormwater generated on directly-connected and adjacent impervious surfaces, the Hub would also provide workforce development activities associated with $\mathrm{Gl}$ installation and maintenance, and retail opportunities associated with sales of rain barrel components, and vegetated "plugs" that could be used in Gl installations in Camden, and nearby Philadelphia (Figure 5). In this way, the design concept builds local capacity through green jobs (the sub-basin's top ranked ecosystem service) with a physical GI strategy that that reduces CSOs and the urban heat island effect (the second and third ranked ecosystem services).

Given that most of the existing lots are undeveloped pervious areas (with the exception of a $111 \mathrm{~m}^{2}$ existing concrete pad), the design would ensure that these spaces remain pervious in perpetuity, while expanding their tributary source area. In addition to these stormwater source areas, the site also presents an opportunity to diffuse knowledge about Gl systems into the surrounding residential neighborhood, for example by distributing rain barrels to local households, or disconnecting local downspouts from the sewer systems. The management of rooftop runoff through such measures is known to be relatively cost effective (US EPA, 2013), and can help to expand the impervious area that can be treated by GI beyond the public right-of-way. It could, in this way, provide private property outreach and extension of Gl application for CCMUA.

The design includes a retail garden center, nursery and greenhouse, as well as a shaded pavilion for flexible market space and additional retail opportunities (Figure 7). Training facilities are proposed; including workshop areas with demonstration rain garden and rain bar- rels (which manage stormwater from onsite and ROW areas), and community spaces can be constructed to provide flexible meeting spaces for events or classes. Local community organizations could use the site for workshops, training, and other gatherings, fostering longterm relationships within the neighborhood.

\subsubsection{Vine and Willard Vacant Lots-Life Cycle Cost Reduction and New Funding Sources}

Obviously, the site would need to be maintained in order to adequately provide the ecosystem services it is designed to provide. It is well established that GI maintenance represents a significant opportunity for urban communities (Water Environment Federation, 2015), by providing new local jobs and environmental education. In Philadelphia, the Community LandCare initiative of the Pennsylvania Horticultural Society works with 18 community organizations, to hire local residents who perform landscape maintenance work on vacant lots in their neighborhood (2017). The GreenHouse program of the Horticultural Society of New York (2017) provides vocational training in horticulture for incarcerated individuals at Rikers Island. Upon their release, graduates of the program may enter a vocational internship program that provides maintenance to gardens, parks, street trees, and green roofs throughout New York City.

Such programs reduce the maintenance burden that decentralized GI creates for public utilities, and could also generate new sources of revenue, further offsetting GI O\&M costs. As an example, Table 4 shows a cursory evaluation of the potential revenue that could be generated by paying local adults $\$ 15 / \mathrm{hr}$, above a living wage, to grow vegetated plugs (assuming two growing seasons per year, with 269 plugs grown per $\mathrm{m}^{2}$ ) at the Vine and Willard Site. The living wage (the hourly wage that an individual must earn to support their family, if

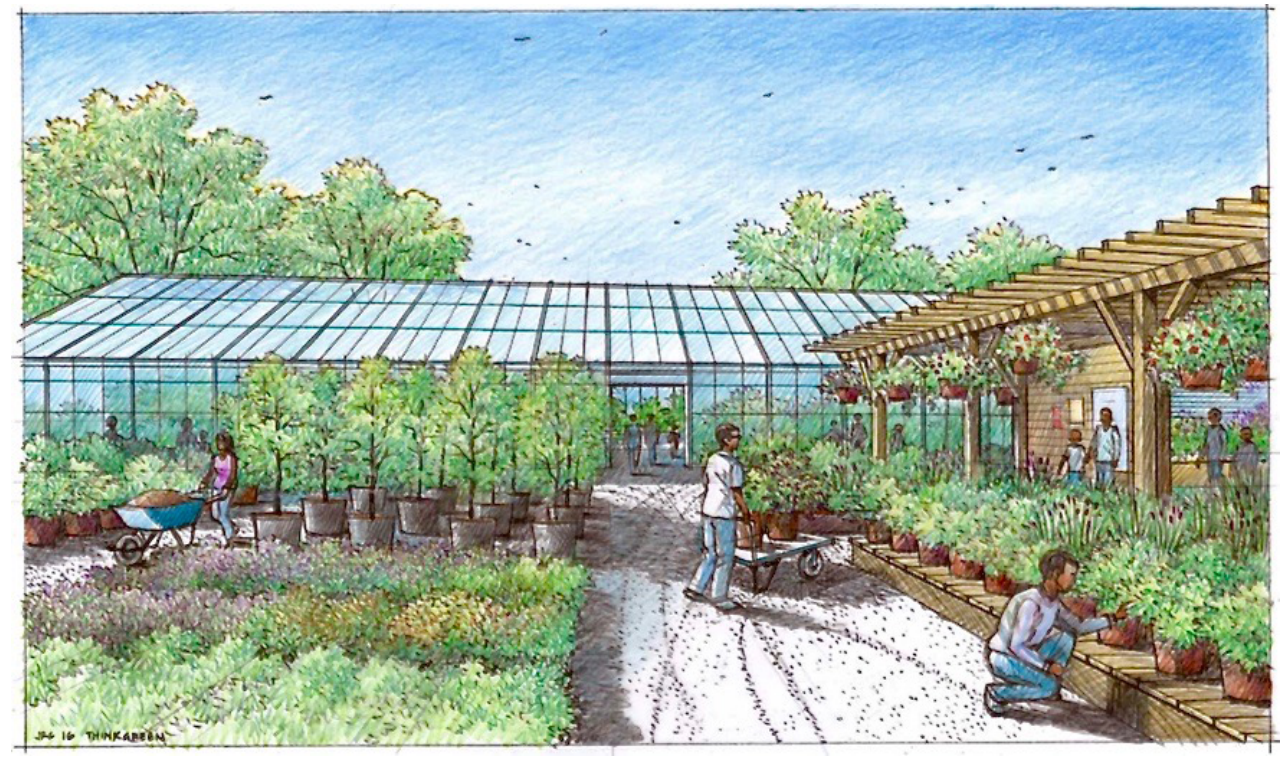

Figure 7. Vine and Willard vacant lots site rendering. Source: ThinkGreen, LLC. 
Table 4. Estimated revenue and costs associated with the Vine and Willard site conceptual design.

\begin{tabular}{|c|c|c|c|c|c|c|c|c|}
\hline \multirow[b]{2}{*}{$\begin{array}{l}\text { Top } \\
\text { Ecosystem } \\
\text { Services }\end{array}$} & \multicolumn{8}{|c|}{ Potential Annual Costs (O\&M) } \\
\hline & Components & Qty & $\begin{array}{l}\text { Unit } \\
\text { Value }\end{array}$ & $\begin{array}{l}\text { Annual } \\
\text { Revenue }\end{array}$ & $\begin{array}{l}\text { Operations and } \\
\text { Maintenance } \\
\text { Tasks }\end{array}$ & Assumptions & $\begin{array}{l}\text { Annual } \\
\text { Hours }\end{array}$ & $\begin{array}{l}\text { Annual } \\
\text { Cost }(\$ 15 / \\
\text { Hour) }\end{array}$ \\
\hline \multirow[t]{6}{*}{$\begin{array}{l}\text { Green } \\
\text { Jobs } \\
\text { Capacity } \\
\text { Building } \\
\text { Expansion } \\
(1.00)\end{array}$} & $\begin{array}{l}\text { Rain garden } \\
\text { plant } \\
\text { production } \\
\left(364 \mathrm{~m}^{2}\right)\end{array}$ & $\begin{array}{l}196,125 \\
\text { PLUGS }\end{array}$ & $\begin{array}{l}\$ 0.85 / \\
\text { PLUG }\end{array}$ & $\$ 166,706$ & $\begin{array}{l}\text { Tilling, } \\
\text { watering, } \\
\text { weeding, } \\
\text { harvesting. }\end{array}$ & $\begin{array}{l}8 \text { hrs per } \\
\text { session, } \\
5 \text { days a week, } \\
10 \text { months } \\
\text { per year }\end{array}$ & 1,600 & $\$ 24,000$ \\
\hline & $\begin{array}{l}\text { Demonstration } \\
\text { rain garden }\end{array}$ & $205 \mathrm{~m}^{2}$ & & & $\begin{array}{l}\text { Remove trash } \\
\text { and sediment. } \\
\text { Weeding } \\
\text { invasives. }\end{array}$ & $\begin{array}{l}2 \text { hrs per } \\
\text { session, twice } \\
\text { a month, } \\
8 \text { months } \\
\text { per year }\end{array}$ & 32 & $\$ 480$ \\
\hline & $\begin{array}{l}\text { Demonstration } \\
\text { roof disconnect } \\
\text { for rain barrels }\end{array}$ & 3 & & & $\begin{array}{l}\text { Remove trash } \\
\text { and sediment. }\end{array}$ & $\begin{array}{l}1 \mathrm{hr} \text { per } \\
\text { session, twice } \\
\text { a month, } \\
8 \text { months } \\
\text { per year }\end{array}$ & 16 & $\$ 240$ \\
\hline & $\begin{array}{l}\text { Retail garden } \\
\text { center and } \\
\text { retail nursery }\end{array}$ & $483 \mathrm{~m}^{2}$ & Flexible & & $\begin{array}{l}\text { Retail } \\
\text { operations } \\
\text { and } \\
\text { management }\end{array}$ & $\begin{array}{l}\text { Demand paired } \\
\text { retail }\end{array}$ & to revenu & from \\
\hline & Workshop space & $69 \mathrm{~m}^{2}$ & & & & & & \\
\hline & Classroom space & $46 \mathrm{~m}^{2}$ & & & & & & \\
\hline \multirow[t]{2}{*}{$\begin{array}{l}\text { Heat } \\
\text { Island } \\
\text { Reduction } \\
(0.93)\end{array}$} & $\begin{array}{l}\text { Rain gardens } \\
\text { installed on } \\
\text { adjacent } \\
\text { private parcels }\end{array}$ & 107 & & & & & & \\
\hline & $\begin{array}{l}\text { Trees provided } \\
\text { for adjacent } \\
\text { rain gardens }\end{array}$ & 107 & & & & & & \\
\hline \multirow[t]{3}{*}{$\begin{array}{l}\text { CSO } \\
\text { Reduction } \\
(0.85)\end{array}$} & $\begin{array}{l}\text { Direct and } \\
\text { adjacent ROW }\end{array}$ & $3,098 \mathrm{~m}^{2}$ & & & $\begin{array}{l}\text { Remove trash } \\
\text { and sediment } \\
\text { from pipes, } \\
\text { and } \\
\text { connections } \\
\text { to Gl areas. }\end{array}$ & $\begin{array}{l}2 \text { hrs per } \\
\text { session, twice } \\
\text { a month, } \\
8 \text { months } \\
\text { per year }\end{array}$ & 32 & $\$ 480$ \\
\hline & $\begin{array}{l}107 \text { parcel level } \\
\text { roof disconnects } \\
\text { ( } 20 \% \text { adoption } \\
\text { rate for parcels } \\
500 \text { ' from site) }\end{array}$ & $6,473 \mathrm{~m}^{2}$ & & & & & & \\
\hline & & & TOTAL & $\$ 166,706$ & & & 1,680 & $\$ 25,200$ \\
\hline
\end{tabular}

they are the sole provider and are working full-time) in Camden is $\$ 12.09$ (Glasmeier, 2017). Figure 8 shows graphically how this concept would entrain local community members in retrofitting the site so that it can provide the locally needed ecosystem services. Further development of a workforce development program would require a detailed market feasibility study as well as specific scaling to current O\&M costs for optimized life cycle cost reduction.

With the recognition that activities such as vacant lot stabilization and workforce development can occur while managing stormwater, multifunctional GI investment on 


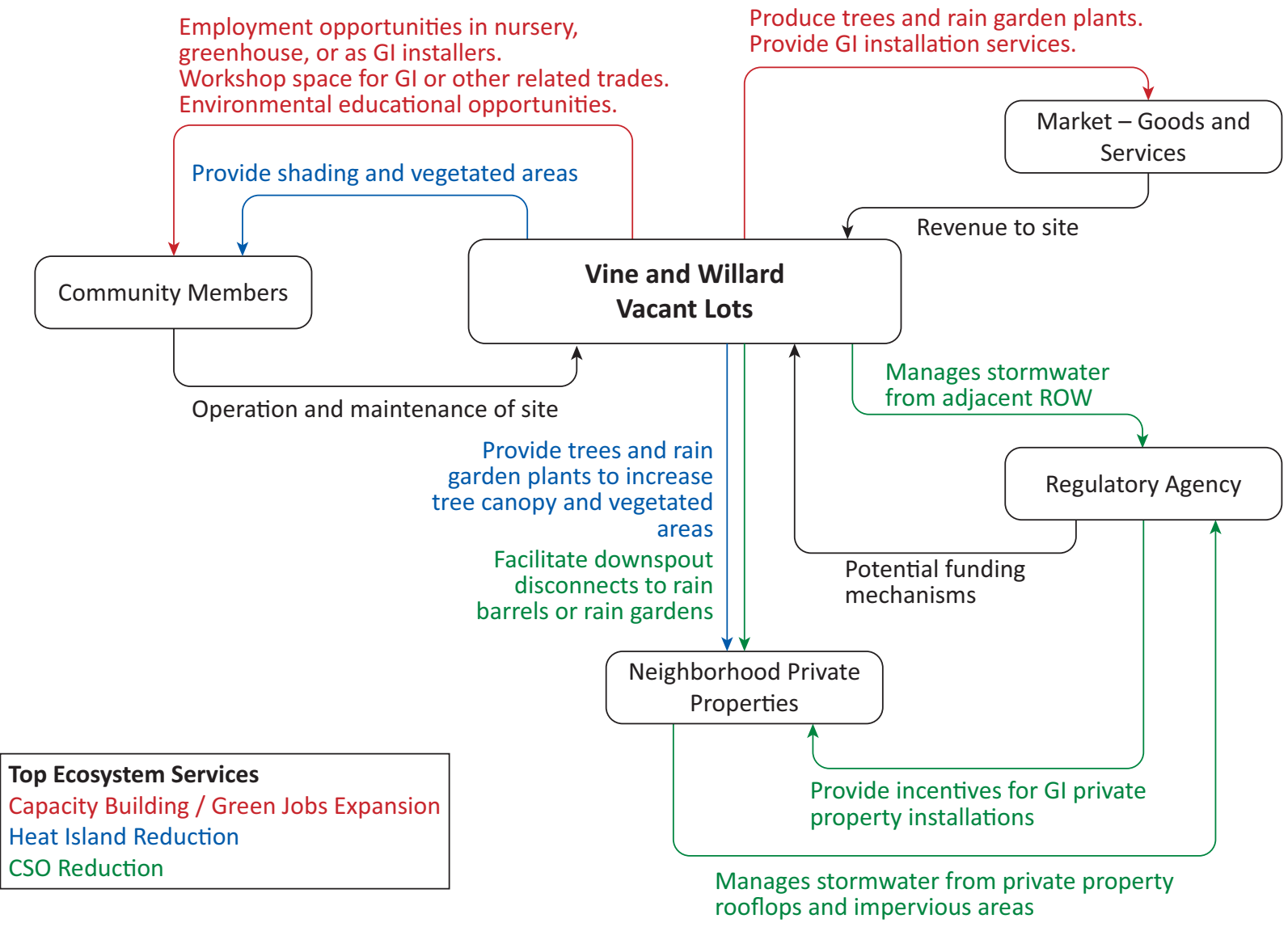

Figure 8. Vine and Willard vacant lots service flow diagram.

a site such as Vine and Willard can be conceived (and financed) as a candidate for many different sources of funding from its inception. In fact, the more multifunctional GI systems become, the greater the number of potential sources of funding for their construction and operation. Currently, CCMUA receives funding for GI development at the federal level through the EPA's Clean Water State Revolving Fund and at the state level through the New Jersey Environmental Infrastructure Trust. The target for these funds is the "Camden City Green and Gray Infrastructure" project, which aims to construct a series of green infrastructure and sewer improvement projects that would manage approximately 30 million gallons of stormwater annually.

However, these same federal and state entities also provide funding for projects that address other environmental and community-oriented goals. EPA's “Urban Waters and Brownfield" program, for example, funds projects that address urban runoff pollution and various brownfield remediation activities. Its "Environmental Education Grants", along with National Oceanographic and Atmospheric Administration's "Environmental Literacy Grants", can also be utilized by educational institutions to promote environmental awareness and stewardship. The National Park Service offers grants to municipalities to expand outdoor park space, like the "Outdoor Recreation Legacy Partnership Program". These open space expansion and protection programs also exist at the local level, such as the "Camden County Open Space, Recreation, Farmland, and Historic Preservation Trust Fund Referendum".

\section{Conclusions}

The goal of this project was to develop a decisionsupport framework for planning Gl systems that maximize urban ecosystem services. Ecosystem service gaps were evaluated and used to geographically prioritize different kinds of multifunctional GI. Conceptual designs were developed for four site typologies: parks, schools, vacant lots, and brownfield sites. An integrated longterm vision was presented whereby multifunctional GI systems, customized to the needs of different communities, manage stormwater while also creating new opportunities for urban engagement, mobilizing various sources of funding, and contributing to an integrated plan for urban revitalization. Such a strategy would leverage the regulatory requirement to manage stormwater to enable many other community improvements, all through a decentralized network of green infrastructure assets.

As the City of Camden and CCMUA finalize development of their respective LTCPs, a complementary planning effort that, through extensive stakeholder deliberation, seeks to develop GI siting and design configurations specially customized to this city's unique physical, in- 
stitutional, demographic, and historic conditions, could help to maximize the full spectrum of benefits achievable through $\mathrm{GI}$ in Camden. The better GI systems are tailored to local conditions, and the more ecosystem services they are designed to provide, the more support the program will have from the public, the more funding sources they will become candidates for, and the more spatial and institutional opportunities there will be for integrating different kinds of GI facilities into the city's complex urban landscape. With more widespread spatial application, of course, comes greater stormwater capture, helping municipalities to more efficiently and costeffectively comply with federally mandated stormwater capture and CSO-abatement goals.

If implemented with broad community participation, the ecosystem services framework presented can help to identify specific geographic opportunities, GI design configurations, and partnership arrangements that can couple flood control, green job growth, heat island mitigation, community engagement, and other ecosystem service targets with stormwater management services. Of course, implementation of this framework at the city scale would require unprecedented levels of interagency coordination, and community outreach and organizing, neither of which are insignificant undertakings. In the long term, the need to green the city for stormwater capture is seen as a vehicle for promoting a broad-ranging discussion about all the ways urban spaces can serve residents of the city, with the LTCP planning process transformed from a plan focused solely on water management to a strategic initiative fostering urban revitalization in Camden, and beyond.

\section{Acknowledgments}

This study was originally prepared for Camden County Municipal Utilities Authority with funding support from New Jersey Health Initiatives, a Robert Wood Johnson Foundation program.

\section{Conflict of Interests}

The authors declare no conflict of interests.

\section{References}

Ahern, J. (2011). From fail-safe to safe-to-fail: Sustainability and resilience in the new urban world. Landscape and Urban Planning, 100(4), 341-343. doi:10.1016/ j.landurbplan.2011.02.021

Barthel, S., \& Isendahl, C. (2013). Urban gardens, agriculture, and water management: Sources of resilience for long-term food security in cities. Ecological Economics, 86, 224-234. doi:10.1016/j.ecolecon. 2012.06.018

Bell, J. F., Wilson, J. S., \& Liu, G. C. (2008). Neighborhood greenness and 2-year changes in body mass index of children and youth. American Journal of Preven- tive Medicine, 35(6), 547-553. doi:10.1016/j.amepre. 2008.07.006

Bolund, P., \& Hunhammar, S. (1999). Ecosystem services in urban areas. Ecological Economics, 29(2), 293-301. doi:10.1016/S0921-8009(99)00013-0

Campbell, L. K. (2014). Constructing New York City's urban forest. The politics and governance of the MillionTreesNYC campaign. In L. A. Sandberg, A. Bardekjian, \& S. Butt (Eds.), Urban forests, trees, and greenspace: A political ecology perspective (pp. 242260). New York: Routledge.

Dunn, A. D. (2010). Siting green infrastructure: Legal and policy solutions to alleviate urban poverty and promote healthy communities. Boston College Environmental Affairs Law Review, 37, 41.

Food, Conservation, and Energy Act of 2008, Public Law 110-234 (7 USC 8701 note), 110th Congress. Retrieved from https://www.govtrack.us/congress/ bills/110/hr6124

Glasmeier, A. K. (2017). Living wage calculator. Cambridge, MA: Massachusetts Institute of Technology. Retrieved from http://livingwage.mit.edu/counties/ 34007

Gómez-Baggethun, E., \& Barton, D. N. (2013). Classifying and valuing ecosystem services for urban planning. Ecological Economics, 86, 235-245. doi:10.1016/ j.ecolecon.2012.08.019

Grant, J., \& Gallet, D. (2010). The value of green infrastructure: A guide to recognizing its economic, environmental and social benefits. Chicago, IL: Center for Neighborhood Technology. Retrieved from http://www.cnt.org/sites/default/files/publications/ CNT_Value-of-Green-Infrastructure.pdf

Gröning, G. (1994). School garden and kleingaerten: For education and enhancing life quality. Horticulture in Human life, Culture and Environment, 391, 53-64. doi:10.17660/ActaHortic.1995.391.4

Konrad, C. P. (2003). Effects of urban development on floods (Fact Sheet 076-03). Tacoma, WA: U.S. Geological Survey. Retrieved from https://pubs.usgs.gov/ $\mathrm{fs} / \mathrm{fs} 07603 /$

Krasny, M. E, \& Tidball, K. G. (2009). Community gardens as contexts for science, stewardship, and civic action learning. Cities and the Environment, 2(1), 1-18.

Millennium Ecosystem Assessment. (2005). Ecosystems and human well-being: Synthesis. Washington, DC: Island Press.

Mitchell, R., \& Popham, F. (2007). Greenspace, urbanity and health: Relationships in England. Journal of Epidemiology \& Community Health, 61(8), 681-683. doi:10.1136/jech.2006.053553

Mittman, T., \& Kloss, C. (2014). The economic benefits of green infrastructure: A case study of Lancaster, PA. Washington, DC: United States Environmental Protection Agency.

Montalto, F., Behr, C., Alfredo, K., Wolf, M., Arye, M., \& Walsh, M. (2007). Rapid assessment of the costeffectiveness of low impact development for CSO 
control. Landscape and Urban Planning, 82(3), 117131. doi:10.1016/j.landurbplan.2007.02.004

Montalto, F. A., Bartrand, T. A., Waldman, A. M., Travaline, K. A., Loomis, C. H., McAfee, C., . . . Boles, L. M. (2013). Decentralised green infrastructure: The importance of stakeholder behaviour in determining spatial and temporal outcomes. Structure and Infrastructure Engineering, 9(12), 1187-1205. doi:10.1080/15732479.2012.671834

National Collaborating Center for Environmental Health. (2010, October). Vulnerable populations. Retrieved from http://www.ncceh.ca/content/vulnerable-pop ulations

Nowak, D. J., \& McPherson, E. G. (1993). Quantifying the impact of trees: The Chicago urban forest climate project. Unasylva, 173(44), 39-44.

Pennsylvania Horticultural Society. (2017). PHS Philadelphia landcare program. Retrieved from https:// thehort.org/horttherapy_greenhouse.html

Schilling, J., \& Logan, J. (2008). Greening the rust belt: A green infrastructure model for right sizing America's shrinking cities. Journal of the American Planning Association, 74(4), 451-466. doi:10.1080/ 01944360802354956

The Horticultural Society of New York. (2017). The hort's greenhouse program. Retrieved from https:// thehort.org/horttherapy_greenhouse.html

The Trust for Public Land. (2004). Camden, New Jersey: The role of parks and greenspace in redevelopment. San Francisco, CA: TPL. Retrieved from http://cloud. tpl.org/pubs/ccpe_camdenNJ_parks_report.pdf

The Trust for Public Land. (2016). Camden green infrastructure GIS viewer. Retrieved from http:// tplgis.org/Climate/GI/Camden

Tidball, K. G., \& Krasny, M. E. (2010). Urban environmental education from a social-ecological perspective: Conceptual framework for civic ecology education. Cities and the Environment, 3(1), 11.
Tyrväinen, L., Pauleit, S., Seeland, K., \& de Vries, S. (2005). Benefits and uses of urban forests and trees. In C. Konijnendijk et al. (Eds.), Urban forests and trees (pp. 81-114). Springer Berlin Heidelberg.

Ulrich, R. S. (1984). View through a window may influence recovery. Science, 224(4647), 224-225. doi:10.1126/science.6143402

Ulrich, R. S., Simons, R. F., Losito, B. D., Fiorito, E., Miles, M. A., \& Zelson, M. (1991). Stress recovery during exposure to natural and urban environments. Journal of Environmental Psychology, 11(3), 201-230. doi:10.1016/S0272-4944(05)80184-7

United States Environmental Protection Agency. (2004). Report to congress: Impacts and control of CSOs and SSOs, (EPA-833-R-04-001). Washington, DC: US EPA Office of Water. Retrieved from https://www.epa. gov/sites/production/files/2015-10/documents/cso ssortc2004_full.pdf

United States Environmental Protection Agency. (2008). Urban heat island basics. In Reducing urban heat islands: Compendium of strategies. Washington, DC: US EPA. Retrieved from https://www.epa.gov/heatislands/heat-island-compendium

United States Environmental Protection Agency. (2013). City of Camden green infrastructure design handbook: Integrating stormwater management into sustainable urban design. Washington, DC: US EPA.

United States Environmental Protection Agency. (2016). What is green infrastructure? US EPA Green Infrastructure. Retrieved from www.epa.gov/greeninfrastructure/what-green-infrastructure

Water Environment Federation. (2015). The need for national green infrastructure training and certification. Alexandria, VA: Water Environment Federation. Retrieved from http://ngicp.org/wp-content/uploads/ 2016/07/White-Paper-The-Need-for-National-Green -Infrastructure-Training-and-Certification.pdf

\section{About the Authors}
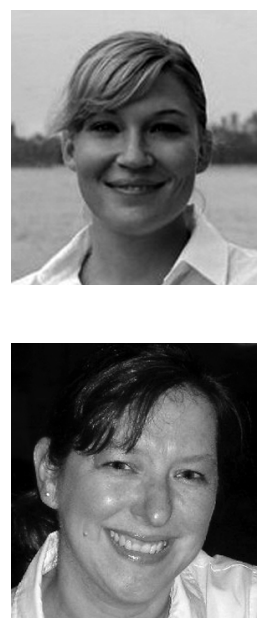

Kate Zidar is an Environmental Planner with a focus on coastal resilience and communications. Kate was a founding member of the Stormwater Infrastructure Matters (S.W.I.M.) Coalition, a policy think tank that figured centrally in establishing Green Infrastructure as a mainstream practice in New York City. She founded the North Brooklyn Compost Project, a community-scale compost operation that preceded citywide collection of organic waste in NYC. Kate taught for a decade at her alma mater, Pratt Institute Graduate Center for Planning and the Environment. She currently works as a consultant throughout the US East Coast, Caribbean and Central America.

Maryse Beliveau-Nance joined TPL's Philadelphia team in November 2013 and leads the development of new community green play spaces in the Parks for People-Philadelphia program. She began her career in the public service at the City of Montreal, Canada and for Washington, DC, where she oversaw the development, restoration and stewardship of parks, playgrounds and open spaces. She settled in Philadelphia after 7 years in the Middle East where she was responsible for the implementation of the public realm component of large master planned development projects. Maryse holds a Bachelor of Landscape Architecture, a Bachelor of Arts and a Graduate Certificate in Project Management from the University of Montreal, Canada. 

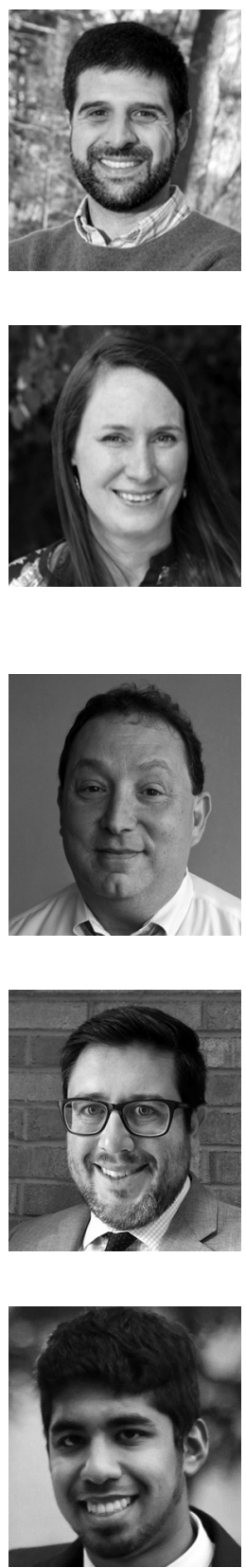

Shudipto Rahman is a Civil Engineer with the Federal Emergency Management Agency (FEMA), working with federal, state, local, and tribal partners to identify flood risk and promote informed planning through the Risk MAP program. At the time of this study, Shudipto was with Boomi Environmental, an environmental consulting firm specializing in municipal water and wastewater. His interest in resilient infrastructure stems from family origins in flood-prone Bangladesh and experience in community development in Pisco, Peru, following the earthquake in 2007.

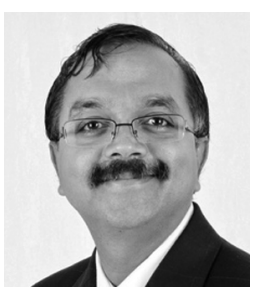

Sri Rangarajan, PhD PEng DWRE, is an environmental engineer with over 27 years of public/private sector experience. His projects have focused on hydrologic, hydraulic, and water quality evaluations to assist municipalities, regional agencies, and private developers in making informed decisions through sound scientific assessments to meet regulatory requirements in a sustainable and cost-effective manner. He is a co-founder and President of Boomi Environmental, an environmental consulting firm that specializes in resilient urban drainage systems and integrated watershed planning/management.

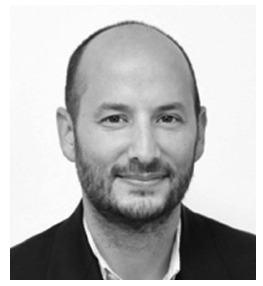

Eric Rothstein is a Managing Partner and Engineer at eDesign Dynamics, and a hydrologist with twenty years of experience working on a variety of sustainability projects. Mr. Rothstein's career has focused on ecosystem restoration and water resources planning within urban centers. He currently leads the team investigating sustainable water resource planning for multiple projects in New York City. His international work includes water resource and ecosystem planning in Nepal, São Paulo, Brazil, rural Rwanda, and the Aegean coast of Turkey. 

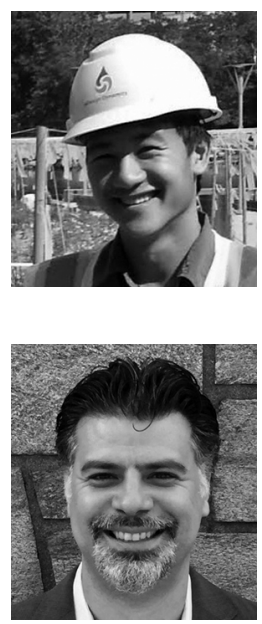

Justin Shih worked as a project engineer for eDesign Dynamics from 2013-2016, where he focused on green stormwater infrastructure and habitat restoration. Justin received his BS in Civil Engineering and $\mathrm{MS}$ in Environmental Engineering from the University of California Berkeley.

Franco Montalto is a civil engineer with a strong background in both applied and theoretical approaches to solving complex environmental problems. He has a particular interest in the development of ecologically, economically, and socially sensible solutions to urban environmental problems, with a focus on sustainable water resources engineering. He joined Drexel in September 2007 after a twoyear research fellowship at The Earth Institute at Columbia University, and adjunct teaching at The Cooper Union for the Advancement of Science and Art in New York City. He also serves as the Director of the North American Hub of the Urban Climate Change Research Network (UCCRN) and is Founder and President of eDesign Dynamics LLC, an environmental consulting firm also based in New York City. 